\title{
GROWTH, EVAPOTRANSPIRATION AND MINERAL CONTENT OF GERBERA UNDER COMBINED SALINITY AND EXCESS BORON
}

\author{
María José GÓMEZ BELLOT*1,3, Giulia CARMASSI², Manuele BARTALUCCI ${ }^{2}$, \\ María Jesús SÁNCHEZ-BLANCO ${ }^{3}$, Alberto PARDOSSI ${ }^{2}$ \\ ${ }^{1}$ Department of Natural Resources, Faculty of Geo-Information Science and Earth Observation (ITC-NRS) \\ University of Twente; Hengelosestraat 99, 7514 AE Enschede, The Netherlands \\ ${ }^{2}$ Department of Agriculture, Food and Environment (DAFE); University of Pisa \\ Via del Borghetto 80-56124, Pisa, Italy \\ ${ }^{3}$ Department of Irrigation, Centro de Edafología y Biología Aplicada del Segura (CEBAS-CSIC) \\ P.O. Box 164, E-30100 Espinardo, Murcia, Spain \\ Received: July 2018; Accepted: April 2019
}

\begin{abstract}
Gerbera is a very important plant widely grown for cut flowers. To check the influence of salinity and boron excess in nutrient solution, nine treatments as factorial combination of three sodium chloride $(\mathrm{NaCl})$ $(1,15$ and $30 \mathrm{mM})$ and three boron $(B)(0.1,1$ and $2 \mathrm{mM})$ concentrations in the nutrient solution were applied during the gerbera cultivation. The effects of experimental treatments on gerbera growth, flowering and the interaction in morphological and nutritional aspects were tested. The formation of leaves, stems and flowers, flower dry mass and evapotranspiration (ET) were more negatively affected when plants were irrigated with $2 \mathrm{mM}$ B than with $0.1 \mathrm{mM} \mathrm{B}$ concentration. High levels of boron (1 and $2 \mathrm{Mm})$ in nutrient solution resulted in leaf chlorosis and necrosis. The severity of leaf burn was correlated with leaf B content. Salinity acted as a protector against boron content in leaves and flowers at $1 \mathrm{Mm} \mathrm{B}$. However, at the $2 \mathrm{Mm}$ $\mathrm{B}$ in nutrient solution, leaf $\mathrm{B}$ accumulation was not reduced by the presence of $\mathrm{NaCl}$ but also increased with the increased levels of salinity. The external levels of boron used in this study, which were found to be the highest in the literature, and the high sensitivity of gerbera to boron, suggested that boron acted as the dominant factor. Lower external boron concentrations would be needed to establish to what extent salinity would be able to mitigate the negative effects of boron.
\end{abstract}

Keywords: boron toxicity; $\mathrm{NaCl}$; nutrient uptake; ornamental plants; cut flowers

\section{INTRODUCTION}

In many areas of the world, increasing shortage of water resources has led to the use of low quality water for crop irrigation, specially reclaimed wastewater and brackish water (Shani \& Dudley 2001). These waters sources are generally characterized by high salinity and concentrations of toxic elements like boron (B), which can negatively affect crop growth and yield. In fact, although boron is an essential micronutrient for plants (Brown et al. 2002), its excess may result in a decrease in plant growth and crop yield (Nasim et al. 2015; Zafar-ul-
Hye et al. 2016), eventually having a lethal effect (Reid et al. 2004).

On many plants, the typical symptoms of excess B are represented by leaf chlorosis, which generally evolves in necrosis starting from the tips and margins of older leaves (Sonmez et al. 2009; Landi et al. 2013a, b). As a consequence of these symptoms, reductions of leaf growth, transpiration and photosynthesis have been observed in many plants irrigated with B concentrations around 6$20 \mathrm{mg} \cdot \mathrm{dm}^{-3}$ (Alpaslan \& Gunes 2001; Bañón et al. 2012b; Landi et al. 2012). Thus, in ornamental crops, B excess in the growing medium or in the 
irrigation water may also affect plant quality and commercial value (Bañón et al. 2012a).

As described above, boron is frequently associated with high salinity, and generally, it is found in arid regions with saline soils and saline irrigation water (Ben-Gal \& Shani 2002). Salinity reduces crop growth and production in sensitive species as a consequence of negative effects on biomass, mineral content, water relations and carbon assimilation (Läuchli \& Grattan 2007).

Many studies have been conducted on the interaction between salinity and B toxicity in horticultural and ornamental species (Yermiyahu et al. 2008; Smith et al. 2010; Alpaslan \& Gunes 2001; Carmassi et al. 2013a; Bañón et al. 2012b). Some of these studies concluded that the effects of excess B are mitigated when the plants are grown under conditions of moderate salinity because salinity reduces plant transpiration and water uptake due to an osmotic effect (Ben-Gal \& Shani 2002; Yermiyahu et al. 2008).

Gerbera is one of the most important greenhouse ornamental crops grown for cut flowers (Vidalie 2007). Several studies have been conducted on the response of this species to salinity stress (Paradiso et al. 2003; Akat et al. 2009; Ganege Don et al. 2010; Carmassi et al. 2013b). Gerbera has been classified as moderately sensitive to salinity (Sonneveld et al. 1999). The maximum salinity without yield reduction in substrate-grown gerbera is $1.5-2.8 \mathrm{dS} \cdot \mathrm{m}^{-1}$. However, plant response to salinity depends on cultivar and growing conditions (Carmassi et al. 2013b). No studies have been conducted in relation to the interaction between salinity and B excess in gerbera. Jeong et al. (2009) reported that in gerbera leaf, the symptoms of B toxicity appeared with concentrations about $395.4 \mathrm{mg} \cdot \mathrm{kg}^{-1} \mathrm{DW}$.

In view of the above, the objective of this study was to determine whether salinity may influence the response of gerbera (Gerbera jamesonii Bolus ex Hook. f.) plants to excess B. The plant response, in terms of plant growth, mineral ions, evapotranspiration (ET) and leaf toxicity symptoms were evaluated in plants growing in pots and irrigated with nutrient solution containing different concentration of sodium chloride $(\mathrm{NaCl})$ and $\mathrm{B}$.

\section{MATERIAL AND METHODS}

\section{Plant material and growth conditions}

On 4 May 2012, gerbera plants (Gerbera jamesonii Bolus ex Hook. f., cv 'Forsa') at full blooming were taken from a local nursery, in $1.5 \mathrm{dm}^{3}$ pots (diameter $17 \mathrm{~cm}$, height $14.8 \mathrm{~cm}$ ) filled with growing medium contained with a peat substrate and perlite 7:3 (v/v). The experiment was conducted between 4 May and 14 July 2012 in a glasshouse equipped with auto-mated side and roof windows (with insect screens) and heating system; ventilation and minimum temperatures were $27^{\circ} \mathrm{C}$ and $15^{\circ} \mathrm{C}$, respectively, at the University of Pisa (Pisa, Italy, latitude $43^{\circ} 43^{\prime} \mathrm{N}$, longitude $\left.10^{\circ} 23^{\prime} \mathrm{E}\right)$. The pots were placed in the glasshouse with a crop density of six plants per $\mathrm{m}^{2}$. The glasshouse was covered with black plastic net (30\% shading rate). Plants were irrigated with the following nutrient solution (stock solution) concentration: $\mathrm{N}^{-\mathrm{NO}_{3}} 10 \mathrm{mM}, \mathrm{N}-\mathrm{NH}_{4} 1 \mathrm{mM}, \mathrm{P} 1 \mathrm{mM}, \mathrm{K}$ $5 \mathrm{mM}$, Ca $3 \mathrm{mM}, \mathrm{Mg} 1.51 \mathrm{mM}, \mathrm{S}_{-} \mathrm{SO}_{4} 1.76 \mathrm{mM}$, $\mathrm{Cl} 0.50 \mathrm{mM}, \mathrm{Fe} 45 \mu \mathrm{M}, \mathrm{Cu} 2.4 \mu \mathrm{M}, \mathrm{Zn} 2.3 \mu \mathrm{M}$, $\mathrm{Mn} 7.3 \mu \mathrm{M}$ and $0.1 \mu \mathrm{M}$. The $\mathrm{pH}$ of nutrient solution in the tank was adjusted to 5.5-6.0 using sodium bicarbonate or sulfuric acid and the electrical conductivity (EC) ranged between 1.5 and $1.7 \mathrm{dS} \mathrm{m}^{-1}$. Gerbera plants were irrigated manually from the top every one or two days, depending on weather conditions. During the application of experimental solutions with $\mathrm{NaCl}$ and $\mathrm{B}$ at different levels, a large volume of nutrient solution ( $1 \mathrm{dm}^{3}$ per pot) was applied at each irrigation event to obtain EC of drainage water similar to the EC of irrigation solution. The measurement was verified after every irrigation, ensured that the $\mathrm{B}$ concentration in the root zone remained very close to the nominal concentration.

On 10 May 2012, one week after planting, nine irrigation treatments were imposed resulting from a factorial combination of three $\mathrm{NaCl}(1,15$ and $30 \mathrm{mM})$ and three $\mathrm{B}\left(\mathrm{H}_{3} \mathrm{BO}_{3}\right)(0.1,1$ and $2 \mathrm{mM})$ concentrations in the nutrient solution. For this purpose, nine small tanks were also placed in the glasshouse, each of which was identified with each irrigation treatment. Each tank was filled with the stock solution plus the corresponding combination of 
$\mathrm{NaCl}$ and $\mathrm{B}$ concentrations. There were twelve plants in each experimental treatment.

\section{Measurements}

At the beginning of the experiment, all flowers were detached from the plants at planting in order to assess the effect of salinity and B levels on flower production. The $\mathrm{pH}$ and $\mathrm{EC}$ from the drainage nutrient solution was daily measured from each treatment, with a Hanna HI 9813 portable $\mathrm{pH} /$ Conductivity Meter in the laboratory (Hanna Instruments, Guipúzcoa, Spain). Daily rate of evapotranspiration (ET) $\left(\mathrm{g} \cdot\right.$ plant $^{-1}$ day $\left.^{-1}\right)$ was determined every day using a Sartorius Cubis electronic MSA balance (Sartorius, Goettingen, Germany). All pots with plants were weighed daily before and after each irrigation, when drainage stopped.

At the end of the experiment, on July 14, leaf area, leaf number, number of flowers and length peduncle was measured. Leaf area was determined with a Tamaya Planix digital planimeter. Different organs of sampled plants were collected for dry mass determination of leaves, flowers (stem and capitulum) and roots. They were immediately washed with tap water, rinsed in distilled water and oven-dried at $80{ }^{\circ} \mathrm{C}$ until constant weight.

The occurrence of B toxicity symptoms (chlorotic and/or necrotic patches at the margins and tips) was also determined at the end of the experiment. The leaves of each sampled plant were photographed with a digital camera and images were processed using Image Tool for Windows (version 3.0; Microsoft, Pullman, WA) to determine the percent ratio of injured area on total area.

At the end of the experiment, dry samples of different plant organs were digested with a mixture of nitric and perchloric acid $\left(\mathrm{HNO}_{3}: \mathrm{HClO}_{4}, 5: 2 \mathrm{v} / \mathrm{v}\right)$ at $230{ }^{\circ} \mathrm{C}$. Potassium and $\mathrm{Na}$ were determined by flame photometry (Flame Photometer 230 VAC 50 $60 \mathrm{~Hz}$ ). The concentrations of $\mathrm{Ca}, \mathrm{Mg}, \mathrm{Cu}, \mathrm{Fe}, \mathrm{Zn}$ and $\mathrm{Mn}$ in the wet digested samples were quantified by atomic absorption spectrophotometry (Varian Model Spectra-AA240 FS, Australia). Phosphorus and $\mathrm{B}$ were determined colorimetrically with the molybdate method (Olsen \& Sommers 1982) and the azomethine-H method (Page et al. 1982), respectively. Nitrate content of plant samples ex- tracted with distilled water was determined colorimetrically using the salicylic acid method (Cataldo et al. 1975). Total nitrogen (N) was determined with an analyzer Flash EA 1112 Series Thermo (ThermoFisher Scientific, Waltham, USA), which treated samples in an oxidation reactor at $900{ }^{\circ} \mathrm{C}$. The content of organic nitrogen was determined as the difference between total $\mathrm{N}$ and $\mathrm{N}-\mathrm{NO}_{3}$. For each parameter measured, four replicates per treatment were used (each replicate consisting of two plants).

The results were analyzed statistically using a completely randomized block design with two factors (B and $\mathrm{NaCl}$ ) at three levels of each parameter. Oneway and two-way analysis of variance (ANOVA) was performed using Stat-graphics Plus 5.1 (Manugistic, Rockville, MD). Ratios and percentages were subjected to an arcsine square-root transformation before statistical analysis to ensure homogeneity of variance. Treatment means were separated with Duncan's Multiple Range Test $(\mathrm{p} \leq 0.05)$.

\section{RESULTS}

Sodium chloride applied at three levels did not affect plant growth and ET significantly (Table 1). In contrast, B concentration in nutrient solution influenced flower formation, leaf area, flower dry mass, stem length and daily ET, which were significantly reduced at $2 \mathrm{mM}$ of $\mathrm{B}$ with respect to the control concentration at $0.1 \mathrm{mM} \mathrm{B}$ (Table 1).

The typical symptoms of B toxicity on gerbera leaves (i.e., leaf chlorosis and necrosis) were observed at 1.0 and $2.0 \mathrm{mM}$ (Fig. 1) regardless of the $\mathrm{NaCl}$ concentration; the severity of leaf damage increased with the B concentration in the nutrient solution. In our study, these symptoms were visible on the oldest leaves (i.e., those that had developed before the beginning of the experiment) of the plants grown at $2 \mathrm{mM}$ B within a few days from the start of treatment; afterwards, they rapidly expanded to the whole plant.

Salinity and B levels did not significantly influence the foliar content of $\mathrm{N}, \mathrm{P}, \mathrm{K}, \mathrm{Ca}, \mathrm{Mg}, \mathrm{Fe}$, $\mathrm{Mn}, \mathrm{Zn}$ and $\mathrm{Cu}$ (data not shown). In addition, the results from leaf $\mathrm{B}$ and $\mathrm{Na}$ content did not differ 
significantly between the old and new leaves; therefore, the data reported in the following figures concern the whole set of leaves remaining on the plants at the end of the experiment. Leaf $\mathrm{B}$ content increased with $\mathrm{B}$ concentration in the nutrient solution (Table 2; Fig. 2A), while regardless of the concentration of $\mathrm{B}$ in the nutrient solution, leaf $\mathrm{B}$ content slightly decreased at the highest level of $\mathrm{Na}$ in the nutrient solution (Table 2). The interaction showed that at $30 \mathrm{mM} \mathrm{NaCl}$ and $1 \mathrm{mM} \mathrm{B}$ in the nutrient solution, $\mathrm{B}$ content in leaves was lower than at 1 or $15 \mathrm{mM} \mathrm{NaCl}$ in nutrient solution (Fig. 2A). Nevertheless, at $2 \mathrm{mM} \mathrm{B}$ in the nutrient solution, the highest $B$ contents in leaves were found at 15 and $30 \mathrm{mM}$ $\mathrm{NaCl}$ (Fig. 2A).

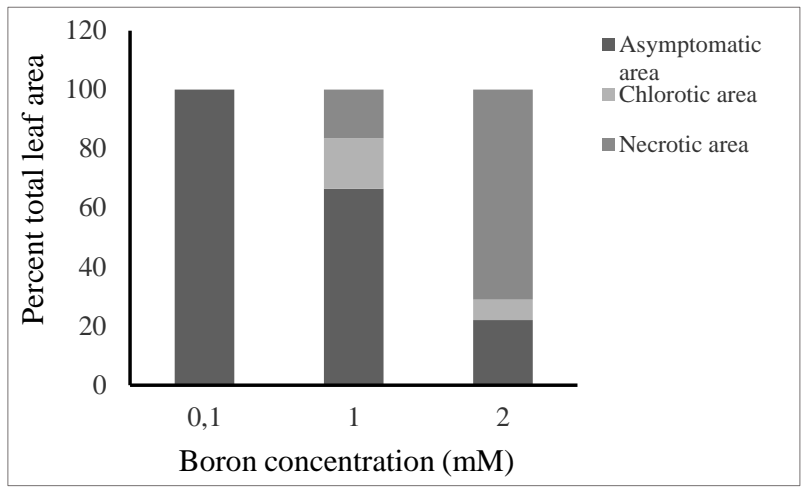

Fig. 1. The severity of leaf chlorosis and necrosis in gerbera plants grown in pot with different boron concentrations in the nutrient solution. The differences among B treatments as regard the damaged area were significantly different at $5 \%$ level. Mean values $(n=8)$

Table 1. Effect of different boron (B) and sodium (Na) concentration in the nutrient solution on growth and evapotranspiration $(\mathrm{ET})$ in gerbera plants $(\mathrm{n}=8)$

\begin{tabular}{|c|c|c|c|c|c|c|c|}
\hline \multicolumn{2}{|c|}{ Treatment } & \multirow[t]{2}{*}{$\begin{array}{c}\text { Flower production } \\
\left(\mathrm{n} \cdot \text { plant }^{-1}\right)\end{array}$} & \multirow[t]{2}{*}{$\begin{array}{l}\text { Plant leaf area } \\
\left(\mathrm{cm}^{2} \cdot \text { plant }^{-1}\right)\end{array}$} & \multirow[t]{2}{*}{$\begin{array}{l}\text { Leaf dry mass } \\
\left(\mathrm{g} \cdot \text { plant }^{-1}\right)\end{array}$} & \multirow[t]{2}{*}{$\begin{array}{c}\text { Flower dry mass } \\
\left(\mathrm{g} \cdot \text { plant }^{-1}\right)\end{array}$} & \multirow[t]{2}{*}{$\begin{array}{c}\text { Stem length } \\
(\mathrm{cm})\end{array}$} & \multirow[t]{2}{*}{$\begin{array}{c}\text { Daily ET } \\
\left(\mathrm{g} \cdot \text { plant }^{-1} \cdot \mathrm{d}^{-1}\right)\end{array}$} \\
\hline $\mathrm{B}$ & $\mathrm{Na}$ & & & & & & \\
\hline 0 & 1 & $3.58 \pm 0.42 \mathrm{ab}$ & $1141.0 \pm 106.2 \mathrm{ab}$ & $4.88 \pm 0.43$ & $10.45 \pm 0.65 \mathrm{a}$ & $35.3 \pm 0.8 \mathrm{a}$ & $86.9 \pm 1.1 \mathrm{a}$ \\
\hline 0 & 15 & $3.33 \pm 0.00 \mathrm{ab}$ & $1331.2 \pm 86.6 \mathrm{a}$ & $4.46 \pm 0.66$ & $9.23 \pm 0.88 \mathrm{ab}$ & $35.5 \pm 0.6 \mathrm{a}$ & $82.0 \pm 0.4 \mathrm{ab}$ \\
\hline 0 & 30 & $4.00 \pm 0.17 \mathrm{a}$ & $1220.1 \pm 94.2 \mathrm{a}$ & $4.61 \pm 0.55$ & $9.98 \pm 1.29 \mathrm{ab}$ & $34.0 \pm 1.3 \mathrm{ab}$ & $80.6 \pm 4.8 \mathrm{ab}$ \\
\hline $\mathrm{B}$ & $\mathrm{Na}$ & & & & & & \\
\hline 1 & 1 & $3.42 \pm 0.08 \mathrm{ab}$ & $955.4 \pm 154.3 \mathrm{ab}$ & $3.70 \pm 0.61$ & $7.53 \pm 0.76 \mathrm{abc}$ & $34.8 \pm 1.1 \mathrm{a}$ & $82.8 \pm 4.8 \mathrm{ab}$ \\
\hline 1 & 15 & $3.67 \pm 0.00 \mathrm{ab}$ & $1144.8 \pm 119.1 \mathrm{ab}$ & $3.95 \pm 0.40$ & $7.00 \pm 0.92 \mathrm{bcd}$ & $34.5 \pm 0.6 \mathrm{a}$ & $83.0 \pm 2.2 \mathrm{ab}$ \\
\hline 1 & 30 & $3.83 \pm 0.33 \mathrm{a}$ & $1233.34 \pm 121.85 \mathrm{a}$ & $4.40 \pm 0.55$ & $8.03 \pm 1.41 \mathrm{abc}$ & $34.0 \pm 1.1 \mathrm{ab}$ & $86.8 \pm 3.5 \mathrm{a}$ \\
\hline $\mathrm{B}$ & $\mathrm{Na}$ & & & & & & \\
\hline 2 & 1 & $3.17 \pm 0.33 \mathrm{ab}$ & $762.10 \pm 58.94 b$ & $3.35 \pm 0.53$ & $5.63 \pm 0.69 \mathrm{~cd}$ & $31.3 \pm 1.4 \mathrm{~b}$ & $76.4 \pm 0.5 b$ \\
\hline 2 & 15 & $2.17 \pm 0.00 c$ & $756.7 \pm 37.5 b$ & $3.95 \pm 0.57$ & $4.28 \pm 0.73 d$ & $30.3 \pm 1.3 b$ & $73.3 \pm 1.5 b$ \\
\hline 2 & 30 & $2.83 \pm 0.33 b c$ & $803.8 \pm 57.7 b$ & $3.48 \pm 0.48$ & $5.15 \pm 0.94 \mathrm{~cd}$ & $30.8 \pm 1.4 \mathrm{~b}$ & $75.4 \pm 2.3 b$ \\
\hline B & & $* *$ & $* * *$ & $\mathrm{~ns}$ & $* * *$ & $* * *$ & $*$ \\
\hline $\mathrm{Na}$ & & ns & ns & ns & ns & ns & ns \\
\hline $\mathrm{Na} \times \mathrm{B}$ & & ns & ns & ns & ns & ns & ns \\
\hline
\end{tabular}

$* * *$ indicate the level of significance at $\mathrm{p} \leq 0.001$, according to Duncan's multiple range test

Table 2. Effect of different boron (B) and sodium (Na) concentration in the nutrient solution on boron and sodium content in leaves, flowers, and roots

\begin{tabular}{llccccccccc}
\hline \multirow{2}{*}{$\begin{array}{c}\text { Mineral concentration } \\
\left(\mathrm{mg} \cdot \mathrm{kg}^{-1} \mathrm{DW}\right)\end{array}$} & \multicolumn{3}{c}{$\mathrm{B}(\mathrm{mM})$} & \multicolumn{3}{c}{$\mathrm{Na}(\mathrm{mM})$} & \multicolumn{3}{c}{ Significance } \\
\cline { 2 - 11 } Leaves & Boron & 127.3 & 879.7 & 1475.7 & 784.6 & 900.2 & 797.9 & $* * *$ & $* * *$ & $* * *$ \\
& Sodium & 8482.0 & 6936.0 & 9602.0 & 1180 & 9310 & 14530 & $* * *$ & $* * *$ & $* * *$ \\
\hline \multirow{2}{*}{ Flowers } & Boron & 64.13 & 141.97 & 384.92 & 200.16 & 195.5 & 195.26 & $* * *$ & $\mathrm{~ns}$ & $* * *$ \\
& Sodium & 6788 & 6822 & 6920 & 1290.0 & 7360 & 11880 & $\mathrm{~ns}$ & $* * *$ & $\mathrm{~ns}$ \\
\hline \multirow{2}{*}{ Roots } & Boron & 74.38 & 131 & 226.87 & 130.06 & 150.7 & 151.46 & $* * *$ & $\mathrm{~ns}$ & $* * *$ \\
& Sodium & 14840 & 14320 & 13840 & 7800 & 16940 & 18260 & $\mathrm{~ns}$ & $* * *$ & $\mathrm{~ns}$ \\
\hline
\end{tabular}

$* * *$ indicate the level of significance at $\mathrm{p} \leq 0.001$, according to Duncan's multiple range test 


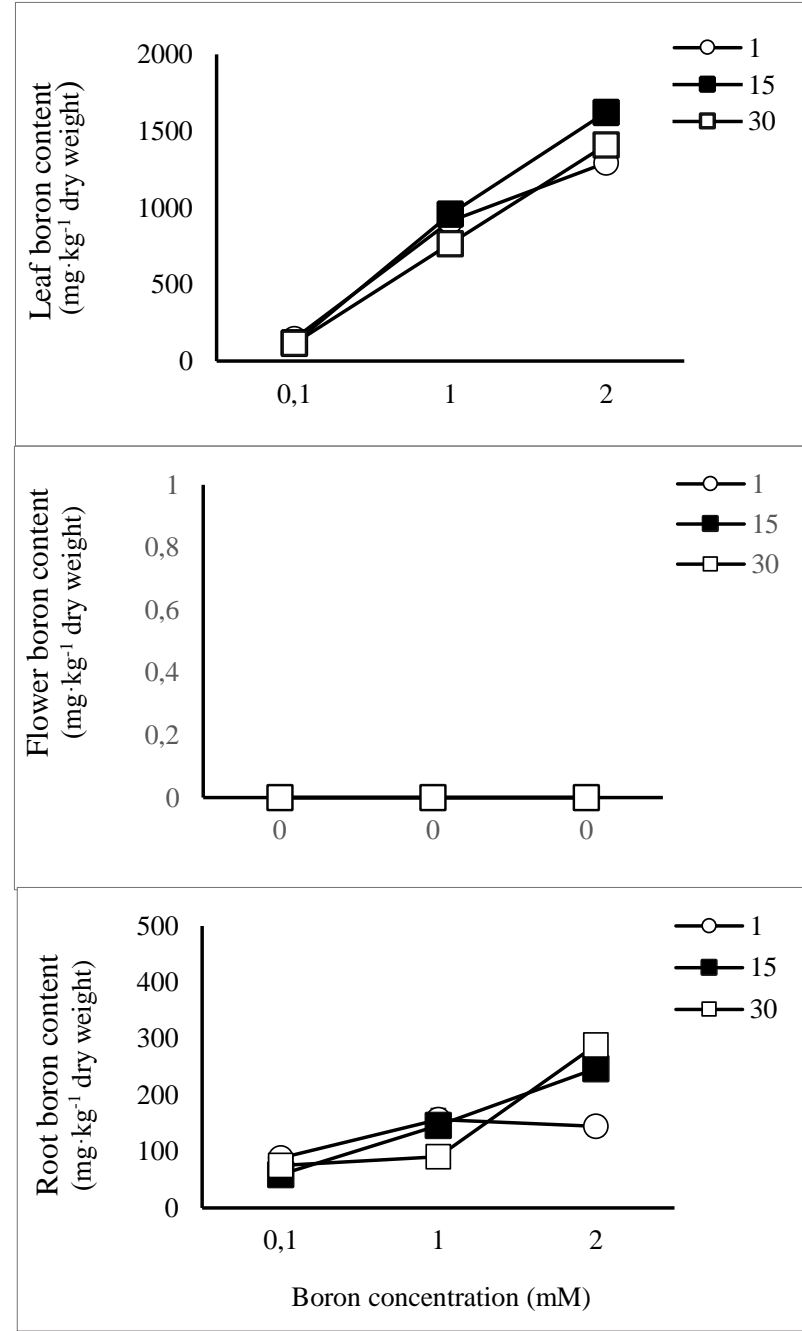

Fig. 2. Boron concentration in leaves (A), flowers (B) and roots (C) of gerbera plants grown in pot with different $\mathrm{B}$ and $\mathrm{NaCl}$ concentrations in the nutrient solution. Asterisks indicate statistically significant differences by Duncan 0.05 test. The vertical bars indicate standard errors $(n=8)$

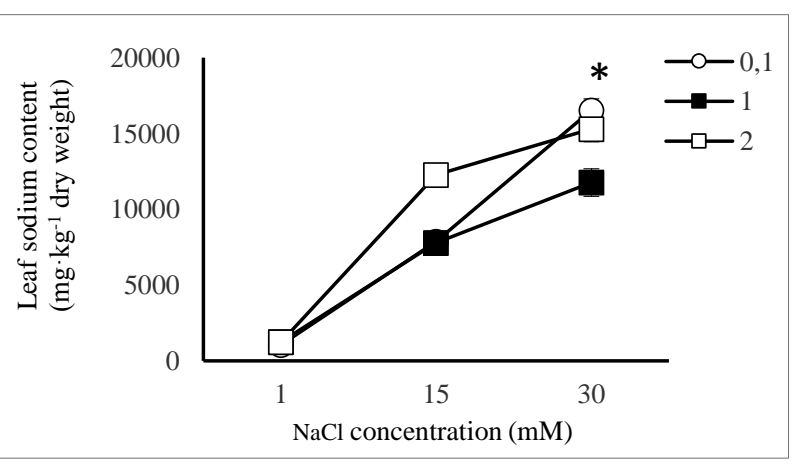

Fig.3. Leaf sodium $(\mathrm{Na})$ concentration in gerbera plants grown in pot with different $\mathrm{B}$ and $\mathrm{NaCl}$ concentrations in the nutrient solution. Asterisks indicate statistically significant differences by Duncan 0.05 test. The vertical bars indicate standard errors $(n=8)$
Increasing B level also enhanced B accumulation in flower and root tissues although to a lesser extent compared with the leaves (Table 2). In addition, regardless of the concentration of $\mathrm{B}$ in the nutrient solution, the presence of $\mathrm{NaCl}$ in the nutrient solution did not significantly affect the accumulation of B in the flower and in the roots. Nevertheless, as regards to $\mathrm{B}$ concentration in flowers, the interaction between both factors showed that at $1 \mathrm{mM} \mathrm{B}$ in nutrient solution, the highest level of $\mathrm{NaCl}(30 \mathrm{mM})$ prevented the accumulation of $\mathrm{B}$ in flowers, while at $2 \mathrm{mM} \mathrm{B}$ in nutrient solution the highest level of $\mathrm{NaCl}$ had the opposite effect (Fig. $2 B)$. The interaction between both factors for the root boron content showed a similar trend to the flower boron content, although less marked (Fig. $2 \mathrm{C})$. On the other hand, the $\mathrm{Na}$ accumulation in flowers and roots increased as $\mathrm{NaCl}$ increased in the nutrient solution, while any statistical differences were observed in $\mathrm{Na}$ accumulation in the same tissues by the effect of boron in the nutrient solution (Table 2).

The leaf $\mathrm{Na}$ content also raised as $\mathrm{Na}$ level increased in the nutrient solution (Table 2), while the effect of $\mathrm{B}$ in the nutrient solution diminished the $\mathrm{Na}$ concentration at $1 \mathrm{mM}$ B in the nutrient solution (Table 2). There was also an interaction between both factors. Leaf sodium content in-creased as $\mathrm{NaCl}$ concentration in nutrient solution was higher. Nevertheless, sodium accumulation in leaves tissues was significantly reduced when the plants were grown at $1.0 \mathrm{mM} \mathrm{B}$ and $30 \mathrm{mM} \mathrm{NaCl}$, while the opposite was observed in the plants irrigated at $2 \mathrm{mM}$ B level and $15 \mathrm{mM} \mathrm{NaCl}$ (Fig. 3).

\section{DISCUSSION}

In our study, gerbera plants tolerated $\mathrm{NaCl}$ salinity up to $30 \mathrm{mM}$, while they were quite sensitive to excess B. Concentration of 1.0 and $2.0 \mathrm{mM}$ B in the nutrient solution rapidly induced the typical symptoms of B toxicity, and, in general, growth was inhibited significantly at the highest B level. Similar results were observed in tomato plants with excess B (Carmassi et al. 2013a); in this species, in spite of leaf burn, the reduction of leaf area was not enough to result in a decrease of photosynthesis. In our case, 
as a consequence of a reduction in the leaf area, ET was reduced.

In plants grown at high B concentration in the root zone, the reduction of the photosynthetic leaf area caused by leaf burn, reduced the overall photosynthetic rate and dry matter accumulation (Landi et al. 2013a, b; Simón et al. 2013).

In gerbera plants, the reduction of leaf area induced by $2 \mathrm{mM}$ B was a result of an inhibition of leaf expansion and not of leaf formation, since the number of leaves showed no statistical differences. Similar results were observed by Jeong et al. (2009). In these plants, reduced leaf area was associated with a greater reduction of ET with respect to the plants grown with lower B concentration in the irrigation water. In contrast to leaf expansion and flower production, root growth was not affected by B level. In fact, excess B may affect differently each organ of the plant (Bañón et al. 2012a). In some species, such as Capsicum annuum L., Laurustinus tinus and Jatropha curcas, the root system is more sensitive to B toxicity than the aerial organs (Yermiyahu et al. 2008; Bañón et al. 2012b; Simón et al. 2013). While in others, such as Hordeum vulgare $\mathrm{L}$. cv schooner, Triticum spp. cv. 'Kenya farmer', Metrosideros excelsa, shoots are more sensitive to B toxicity than roots (Nable 1988; Bañón et al. 2012b).

Once absorbed, B is transported to the shoot in the xylem driven by transpiration flux and tends to accumulate especially where leaf veins terminate, at the leaf edges. These tissues indeed display the most severe symptoms of B toxicity (Shelp et al. 1995). In other species that produce phloem-mobile B-polyol complexes (Brown \& Shelp 1997), B is uniformly distributed within the plant or even at a higher concentration in young tissues than in mature leaves (Camacho-Cristóbal et al. 2008). In gerbera plants exposed to high $\mathrm{B}$ concentration in the nutrient solution, chlorosis and necrosis were observed first on the oldest leaves due to a higher B content in old than in young leaves at the first steps (Wimmer et al. 2015). This suggests that in gerbera, B was translocated via the xylem from the root to the leaves (Shelp et al. 1995). However, the symptoms appeared rapidly in all the leaves.
Leaf concentration of $\mathrm{N}, \mathrm{P}, \mathrm{K}, \mathrm{Ca}, \mathrm{Mg}, \mathrm{Fe}, \mathrm{Mn}$, $\mathrm{Zn}$ and $\mathrm{Cu}$ were not affected by experimental treatments and they were in accordance with the normal range reported for gerbera (Mills \& Jones 1996). Nevertheless, the severity of the damage expressed as a percentage of necrotic leaf area, increased with the concentration of $\mathrm{B}$ in the nutrient solution, in agreement with those reported by other authors (Smith et al. 2010, Bañon et al. 2012b; Carmassi et al. 2013a; Landi et al. 2013b). Leaf damage induced by excess $B$ was not attenuated by high salinity of the nutrient solution. At $1 \mathrm{mM} \mathrm{B}$ in the nutrient solution, only the highest salinity level $(30 \mathrm{~mm} \mathrm{NaCl})$ reduced the $\mathrm{B}$ concentration in leaves. However, at the highest B level in the nutrient solution $(2 \mathrm{mM}$ B), the presence of high levels of $\mathrm{NaCl}$ in nutrient solution (15 and $30 \mathrm{mM} \mathrm{NaCl}$ ) favored the leaf $\mathrm{B}$ accumulation (Farooq et al. 2015). These results are in contrast with previous findings in other crops (Edelstein et al. 2005; Yermiyahu et al. 2007; Smith et al. 2010; Bañon et al. 2012a, b). In our study, higher B concentrations were used than those applied by other authors (e.g., Ben-Gal \& Shani 2002; Edelstein et al. 2005; Yermiyahu et al. 2007) with values that do not exceed $0.7 \mathrm{mM}$ of boron (Yermiyahu et al. 2007). Evapotranspiration rate was unaffected by salinity and it was reduced only at the highest B concentration, contrary to what Bañón et al. (2012a) found in geranium plants. These conditions stimulated the uptake of $\mathrm{B}$ and prevented the ameliorating effect of $\mathrm{NaCl}$, which depends on the reduction of root water uptake, at least partially (Wimmer \& Goldbach 2012).

Boron was less accumulated in flowers and roots than in leaves. As regards gerbera flowers, salinity exerted a protective action against $\mathrm{B}$, but only for relatively moderate concentrations (1 mM B). At concentrations of $2 \mathrm{mM} \mathrm{B}$, in fact, the presence of a high concentration of $\mathrm{NaCl}$ favored the accumulation of $\mathrm{B}$ in flowers. The $\mathrm{B}$ amount in roots was linked to the $\mathrm{B}$ amount in nutrient solution, and therefore, this confirms that these plants do not have the ability to exclude the absorption of B in small quantities, unlike tolerant plants. Nevertheless, the roots accumulated much less B than leaf tissues in agreement with other authors (Kaur et al. 2006; 
Carmassi et al. 2013a), probably due to boron being passively transported through the transpiration stream and tending to accumulate in the vegetative tissues.

Notably, B level influenced leaf accumulation of $\mathrm{Na}$ since $1 \mathrm{mM} \mathrm{B}$ in the nutrient solution reduced the accumulation of $\mathrm{Na}$ with respect to the control, whereas a B concentration of $2 \mathrm{mM}$ had the opposite effect. Other previous studies on wheat, pepper and geranium showed that leaf $\mathrm{Na}$ content decreased in the presence of boron (Holloway \& Alston 1992; Grieve \& Poss 2000; Bañón et al. 2012a). Some of them hypothesized that the decreased leaf $\mathrm{Na}$ accumulation was due to the reduction in rooting density caused by the B treatments. However, in our experiment, root growth was not affected by boron toxicity. Therefore, other different mechanisms were involved. The accumulation of $\mathrm{NaCl}$ and $\mathrm{B}$ within the plants may depend on the competition between both elements for uptake by the roots (Bañón et al. 2012b) and/or for transport within the plant (Grattan \& Grieve 1999), which in turn depend on the degree of tolerance of the species under consideration (Alpaslan \& Gunes 2001).

As the relationship between B content in nutrient solution and salinity was complex (Bastías et al. 2010), several hypotheses are established. Many authors suggest that in the presence of multiple stressors, when the effect of one stress factor on plant response is particularly strong, the influence of the second stressor will be minor (Shani et al. 2005; Grieve et al. 2010).

\section{CONCLUSIONS}

In our case, B content in the nutrient solution might be the dominant stress factor due to the high external concentration and the sensitivity of gerbera plants to boron. Only at moderate concentration of B in nutrient solution (1 Mm B), salinity was able to mitigate the boron accumulation in leaves and flowers. In our conditions, salinity and boron had a synergistic effect on leaves, flowers and roots at the highest $\mathrm{B}$ external concentration $(2 \mathrm{mM})$, since at the highest B external concentration, the highest $\mathrm{NaCl}$ external concentration en- hanced the B concentration in these tissues. Therefore, the explanation for our results may lie in the range of salinities and external $\mathrm{B}$ concentrations used, the composition of the irrigation waters, and/or the tolerance degree of the crop species used in the study. Due to the high external boron concentration in brackish water sources used for horticultural purposes and the fact that there are no previous studies on this subject in gerbera, lower external boron concentrations would be needed to apply for these plants. This would help to establish to what extent salinity would be able to mitigate the negative effects of boron.

\section{REFERENCES}

Alpaslan M.A., Gunes A. 2001. Interactive effects of boron and salinity stress on the growth, membrane permeability and mineral composition of tomato and cucumber plants. Plant and Soil 236: 123-128. DOI: 10.1023/a:1011931831273.

Akat Ö., Tüzel I.H., Özzambak M.E. 2009. The effects of different salinity levels and leaching fractions on yield and water consumption of gerbera plants. Acta Horticulturae 807: 233-238. DOI: 10.17660/actahortic.2009.807.30.

Bañón S., Miralles J., Valdés R., Conesa E., Franco J.A., Sánchez-Blanco M.J. 2012a. Agronomical and physiological response of geranium to salinity and boron toxicity. Acta Horticulturae 952: 959-965. DOI: 10.17660/actahortic.2012.952.122.

Bañón S., Miralles J., Ochoa J., Sánchez-Blanco M.J. $2012 \mathrm{~b}$. The effect of salinity and high boron on growth, photosynthetic activity and mineral contents of two ornamental shrubs. Horticultural Science 39: 188-194. DOI: 10.17221/167/2011-hortsci.

Bastías E., Alcaraz-López C., Bonilla I., MartínezBallesta M.C., Bolaños L., Carvajal M. 2010. Interactions between salinity and boron toxicity in tomato plants involve apoplastic calcium. Journal of Plant Physiology 167: 54-60. DOI: 10.1016/j.jplph.2009.07.014.

Ben-Gal A., Shani U. 2002. Yield, transpiration and growth of tomatoes under combined excess boron and salinity stress. Plant and Soil 247: 211-221. DOI: $10.1023 / \mathrm{a}: 1021556808595$.

Brown P.H., Shelp B.J. 1997. Boron mobility in plants. Plant and Soil 193: 85-101. DOI: 10.1023/a:1004211925160. 
Brown P.H., Bellaloui N., Wimmer M.A., Brassil E.S., Ruiz J., Hu H. et al. 2002. Boron in plant biology. Plant Biology 4: 205-223. DOI: 10.1055/s-200225740.

Camacho-Cristóbal J.J., Rexach J., González-Fontes A. 2008. Boron in plants: deficiency and toxicity. Journal of Integrative Plant Biology 50: $1247-$ 1255. DOI: 10.1111/j.1744-7909.2008.00742.x.

Carmassi G., Romani R., Diara C., Massa D., Maggini R., Incrocci L., Pardossi A. 2013a. Response to sodium chloride salinity and excess boron in greenhouse tomato grown in semi-closed substrate culture in a Mediterranean climate. Journal of Plant Nutrition 36: 1025-1042. DOI: 10.1080/01904167.2013.766209.

Carmassi G., Bacci L., Bronzini M., Incrocci L., Maggini R., Bellocchi G., Massa D., Pardossi A. 2013b. Modelling transpiration of greenhouse gerbera (Gerbera jamesonii H. Bolus) grown in substrate with saline water in a Mediterranean climate. Scientia Horticulturae 156: 9-18. DOI: 10.1016/j.scienta.2013.03.023.

Cataldo D.A., Maroon M., Schrader L.E., Youngs V.L. 1975. Rapid colorimetric determination of nitrate in plant tissue by nitration of salicylic acid. Communications in Soil Science and Plant Analysis 6: 7180. DOI: 10.1080/00103627509366547.

Edelstein M., Ben-Hur M., Cohen R., Burger Y., Ravina I. 2005. Boron and salinity effects on grafted and non-grafted melon plants. Plant and Soil 269: $273-$ 284. DOI: $10.1007 / \mathrm{s} 11104-004-0598-4$.

Farooq M.A., Saqib Z.A., Akhtar J., Bakhat H.F., Pasala R.K., Dietz K.-J. 2015. Protective role of silicon (Si) against combined stress of salinity and boron (B) toxicity by improving antioxidant enzymes activity in rice. Silicon, 5 p. DOI: 10.1007/s12633-015-9346-Z.

Ganege Don K.K., Xia Y.P., Zhu Z., Le CH., Wijeratne A.W. 2010. Some deleterious effects of long-term salt stress on growth, nutrition, and physiology of gerbera (Gerbera jamesonii L.) and potential indicators of its salt tolerance. Journal of Plant Nutrition 33: 2010-2027. DOI: 10.1080/01904167.2010.512058.

Grattan S.R., Grieve C.M. 1999. Salinity mineral nutrient relations in horticultural crops. Scientia Horticulturae 78: 127-157. DOI: 10.1016/s0304-4238(98)00192-7.

Grieve C.M., Poss J.A. 2000. Wheat response to interactive effects of boron and salinity. Journal of Plant Nutrition 23: 1217-1226. DOI: 10.1080/01904160009382095.

Grieve C.M., Poss J.A., Grattan S.R., Suarez D.L., Smith T.E. 2010. The combined effects of salinity and ex- cess boron on mineral ion relations in broccoli. Scientia Horticulturae 125: 179-187. DOI: 10.1016/j.scienta.2010.03.012.

Holloway R.E., Alston A.M. 1992. The effects of salt and boron on growth of wheat. Australian Journal of Agricultural Research 43: 987-1001. DOI: 10.1071/ar9920987.

Jeong K.Y., Whipker B., McCall I., Gunter C., Frantz J. 2009. Characterization of nutrient disorders of gerbera hybrid 'Festival Light Eye Pink' . Acta Horticulturae 843: 177-182. DOI: 10.17660/actahortic.2009.843.22.

Kaur S., Nicolas M.E., Ford R., Norton R.M., Taylor P.W.J. 2006. Physiological mechanisms of tolerance to high boron concentration in Brassica rapa. Functional Plant Biology 33: 973-980. DOI: 10.1071/fp06111.

Landi M., Degl'Innocenti E., Pardossi A., Guidi L. 2012. Antioxidant and photosynthetic responses in plants under boron toxicity: a review. American Journal of Agricultural and Biological Sciences 7: 255270. DOI: 10.3844/ajabssp.2012.255.270.

Landi M., Pardossi A., Remorini D., Guidi L. 2013a. Antioxidant and photosynthetic response of a purpleleafed and a green-leafed cultivar of sweet basil (Ocimum basilicum) to boron excess. Environmental and Experimental Botany 85: 64-75. DOI: 10.1016/j.envexpbot.2012.08.008.

Landi M., Remorini D., Pardossi A., Guidi L. 2013b. Purple versus green-leafed Ocimum basilicum: Which differences occur with regard to photosynthesis under boron toxicity? Journal of Plant $\mathrm{Nu}-$ trition and Soil Science 176: 942-951. DOI: 10.1002/jpln.201200626.

Läuchli A., Grattan S.R. 2007. Plant growth and development under salinity stress. In: Jenks M.A., Hasegawa P.M., Jain S.M. (Eds.), Advances in molecular breeding toward drought and salt tolerant crops. Springer, pp. 1-32. DOI: 10.1007/978-14020-5578-2_1.

Mills H.A., Jones J.B. 1996. Plant Analysis Handbook II. A practical sampling, preparation, analysis, and interpretation guide. Micro-Macro, USA, $422 \mathrm{p}$.

Nable R.O. 1988. Resistance to boron toxicity amongst several barley and wheat cultivars: a preliminary examination of the resistance mechanism. Plant and Soil 112: 45-52. DOI: 10.1007/bf02181751.

Nasim M., Rengel Z., Aziz T., Regmi B.D., Saqib M. 2015. Boron toxicity alleviation by zinc application in two barley cultivars differing in tolerance to boron 
toxicity. Pakistan Journal of Agricultural Science 52(1): 151-158.

Olsen S.R., Sommers E.L. 1982. Phosphorus. Methods of Soil Analysis II. In: Page A.L. (Ed.), Agronomy. American Society of Agronomy, p. 403-430.

Page A.L., Miller R.H., Keeney D.R. 1982. Chemical and Microbiological Properties, In: Page A.L., (Ed.), Methods of Soil Analysis, 2 ${ }^{\text {nd }}$ ed. Agronomy. American Society of Agronomy.

Paradiso R., De Pascale S., Aprea F., Barbieri G. 2003. Effect of electrical conductivity levels of nutrient solution on growth, gas exchanges and yield of two gerbera cultivars in soilless system. Acta Horticulturae 609: 165-171. DOI: 10.17660/actahortic.2003.609.22.

Reid R.J., Hayes J.E., Post A., Stangoulis J.C.R., Graham R.D. 2004. A critical analysis of the causes of boron toxicity in plants. Plant, Cell and Environment 27: 1405-1414. DOI: 10.1111/j.13653040.2004.01243.x.

Shani U., Dudley L.M. 2001. Field studies of crop response to drought and salt stress. Soil Science Society of America Journal 65: 1522-1528. DOI: 10.2136/sssaj2001.6551522x.

Shani U., Ben-Gal A., Dudley L.M. 2005. Environmental implications of adopting a dominant factor approach to salinity management. Journal of Environmental Quality 34: 1455-1460. DOI: 10.2134/jeq2004.0366.

Shelp B.J., Marentes E., Kitheka A.M., Vivekanandan P. 1995. Boron mobility in plants. Physiologia Plantarum 94: 356-361. DOI: 10.1111/j.13993054.1995.tb05323.x.

Simón I., Díaz-López L., Gimeno V., Nieves M., Pereira W.E., Martínez V. et al. 2013. Effects of boron excess in nutrient solution on growth, mineral nutrition, and physiological parameters of Jatropha curcas seedlings. Journal of Plant Nutrition and Soil Science 176(2): 165-174. DOI: 10.1002/jpln.201100394.
Smith T.E., Grattan S.R., Grieve C.M., Poss J.A., Suarez D.L. 2010. Salinity's influence on boron toxicity in broccoli: I. Impacts on yield, biomass distribution, and water use. Agricultural Water Management 97: 777-782. DOI: 10.1016/j.agwat.2010.01.014.

Sonmez O., Aydemir S., Kaya C. 2009. Mitigation effects of mycorrhiza on boron toxicity in wheat (Triticum durum) plants. New Zealand Journal of Crop and Horticultural Science 37: 99-104. DOI: 10.1080/01140670909510254.

Sonneveld C., Baas R., Nijssen H.M.C., de Hoog J. 1999. Salt tolerance of flower crops grown in soilless culture. Journal of Plant Nutrition 22: 1033-1048. DOI: $10.1080 / 01904169909365692$.

Vidalie H. 2007. Varietal richness and technology for gerbera. PHM - Revue Horticole 497: 33-41.

Wimmer M.A., Goldbach H.E. 2012. Boron-and-salt interactions in wheat are affected by boron supply. Journal of Plant Nutrition and Soil Science 175: 171-179. DOI: 10.1002/jpln.201200006.

Wimmer M.A., Goldberg S., Gupta U.C. 2015. Essential elements: micronutrients. Boron. In: Barker A.V., Pilbeam D.J. (Eds.), Handbook of Plant Nutrition, $2^{\text {nd }}$ ed. CRC Press, p. 305-346. DOI: 10.1201/b18458-11.

Yermiyahu U., Ben-Gal A., Sarig P., Zipilevitch E. 2007. Boron toxicity in grapevine (Vitis vinifera L.) in conjunction with salinity and rootstock effects. Journal of Horticultural Science and Biotechnology 82: 547554. DOI: 10.1080/14620316.2007.11512272.

Yermiyahu U., Ben-Gal A., Keren R., Reid R.J. 2008. Combined effect of salinity and excess boron on plant growth and yield. Plant and Soil 304: 73-87. DOI: $10.1007 / \mathrm{s} 11104-007-9522-z$.

Zafar-ul-Hye M., Munir K., Ahmad M., Imran M. 2016. Influence of boron fertilization on growth and yield of wheat crop under salt stress environment. Soil and Environment 35(2): 181-186. 